\title{
Port-wine stain, limb hypertrophy, dilated veins and blue sclera: Klippel-Trenaunay syndrome
}

\author{
Indar Kumar Sharawat, ${ }^{\circledR}$ Vichithra Mohandoss, Lokesh Saini
}

Department of Pediatrics, Post Graduate Institute of Medical Education and Research, Chandigarh, India

\section{Correspondence to} Dr Lokesh Saini, drlokeshsaini@gmail.com

Accepted 31 July 2019

\section{Check for updates}

(C) BMJ Publishing Group Limited 2019. No commercial re-use. See rights and permissions. Published by BMJ.

\footnotetext{
To cite: Sharawat IK, Mohandoss V, Saini L. BMJ Case Rep 2019;12:e230146. doi:10.1136/bcr-2019230146
}

\section{DESCRIPTION}

A 9-year-old boy presented with the concern of purplish-red discolouration of trunk and limbs noted since birth. These lesions were non-pruritic, painless and initially were pink in colour and gradually became purple to red. There was no history of seizures, vision impairment, focal neurological deficit and cognitive impairment. Family history was unremarkable. On examination, he had normal anthropometry, normal development, blue sclera, port-wine stain over the left side of the chest, left axilla, left upper limb, abdomen and bilateral lower limbs, hypertrophied left upper limb and dilated and tortuous veins over the left hand and lower limbs (figure 1). There was no history of recurrent ulceration and bleeding from the lesions. His neurological and other systemic examinations were unremarkable. Ultrasound abdomen and Doppler ultrasound study of a left upper limb did not reveal any abnormality. Based on clinical history and examination, a diagnosis of Klippel-Trenaunay syndrome (KTS) was concluded. Genetic confirmation of a PIK3CA mutation was not performed due to parental refusal. The child was started on intermittent compression therapy and parents were counselled about the nature of the disease.

KTS also called as capillary lymphatic venous malformation is a rare sporadic disorder, first described by Klippel and Trenaunay in $1900,{ }^{1}$ characterised by a triad of port-wine stain (capillary haemangioma), soft tissue or bony overgrowth of an extremity and complex vascular malformation. The estimated incidence of KTS is $0.02-0.05$ per 1000 live births. ${ }^{2}$ Oduber and colleagues ${ }^{2}$ defined KTS by two major features, that is, congenital vascular malformation (capillary malformations, venous malformations, arteriovenous malformations and lymphatic malformations) and disturbed growth of bone and soft tissue (hypertrophy or hypotrophy). For the diagnosis, one should have at least one feature from both the groups. The underlying aetiology is largely unknown and different authors have postulated various theories including disturbed fetal vasculogenesis, mesodermal defects and somatic mosaicism. ${ }^{3}$ Hypertrophy of affected extremity is common due to underlying soft tissue or adipose tissue hyperplasia and lymphoedema. Rarely, it may be associated with bony hypertrophy that can lead to a limb-length discrepancy. Our child had left upper limb hypertrophy and limblength discrepancy (which was slowly progressive) due to soft tissue hyperplasia, lymphoedema and probable bony hypertrophy. The most common cutaneous feature of KTS is capillary malformation

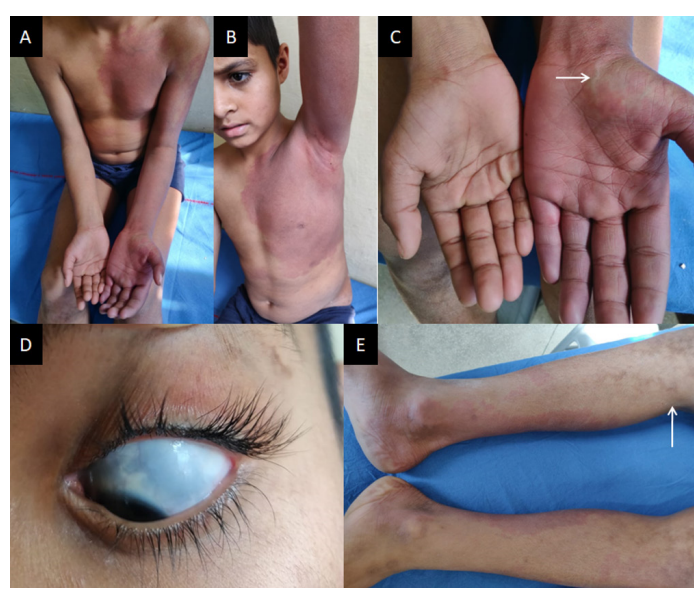

Figure 1 Photographs of the child with KlippelTrenaunay syndrome showing large port-wine stain involving left side of chest, left shoulder, left entire upper limb, abdomen and bilateral lower limbs (A, B and E). There are few engorged and tortuous vessels over affected area ( $C$ and $E$, arrow). Note is made of bilateral blue sclera (D).

or port-wine stain and usually seen over the hypertrophied limb. Although any part of the body can be involved, in $95 \%$ cases, lower limbs are affected.

Vascular anomalies are usually complex that combine venous, capillary and lymphatic components and involve cutaneous or deep structures

\section{Learning points}

Klippel-Trenaunay syndrome is characterised by a triad of capillary haemangioma, overgrowth of an extremity and complex vascular malformation.

- Hypertrophy of affected extremity is due to underlying soft tissue or adipose tissue hyperplasia and lymphoedema.

- Parkes Weber syndrome, Beckwith-Wiedemann syndrome, Maffucci syndrome, CHILD syndrome, proteus syndrome, lymphatic filariasis and Russell-Silver syndrome are the close differentials.

- Management is usually conservative and includes compression or intermittent pneumatic stocking, manual decongestive therapy, orthopaedic devices, laser ablation, embolisation and sclerotherapy.

- Sirolimus, low-dose steroids and propranolol have been used in the treatment of KTS with variable success. 
(colon, rectum, genitourinary tract, pulmonary veins, cerebral vessels and eyes). Intraocular venous malformations and congestion might have contributed to the blue sclera in the index child. KTS should be differentiated from Parkes Weber syndrome, Beckwith-Wiedemann syndrome, Maffucci syndrome, CHILD syndrome, Proteus syndrome, neurofibromatosis type 1, lymphatic filariasis and Russell-Silver syndrome. ${ }^{3}$ Very rarely KTS can overlap with Sturge-Weber syndrome. Management is usually conservative and includes compression or intermittent pneumatic stocking, manual decongestive therapy, orthopaedic devices (height-corrected footwears), laser ablation, embolisation and sclerotherapy on case to case basis. Rare cases may require surgery for varicose veins. Sirolimus, low-dose steroids and propranolol have been used in the treatment of KTS with variable success. In the index case, Doppler study did not reveal any malformation so we did not plan for embolisation and sclerotherapy. However, the child was started on intermittent compression therapy and we reserved propranolol therapy for progressive symptoms.
Contributors IKS: patient management, literature review and initial draft of manuscript preparation; critical review of manuscript for important intellectual content. VM: patient management and initial draft of manuscript preparation. LS: clinician in charge, critical review of manuscript for important intellectual content, and final approval of the version to be published; act as a guarantor of the manuscript.

Funding The authors have not declared a specific grant for this research from any funding agency in the public, commercial or not-for-profit sectors.

Competing interests None declared.

Patient consent for publication Parental/guardian consent obtained.

Provenance and peer review Not commissioned; externally peer reviewed.

\section{REFERENCES}

1 Klippel M, Trenaunay P. Memoires originaux: du noevus variqueux osteohypertrophique. Arch Gen Med 1900:641-72. Tome III.

2 Oduber CE, van der Horst CM, Hennekam RC. Klippel-Trenaunay syndrome: diagnostic criteria and hypothesis on etiology. Ann Plast Surg 2008;60:217-23.

3 Sung HM, Chung HY, Lee SJ, et al. Clinical Experience of the Klippel-Trenaunay Syndrome. Arch Plast Surg 2015;42:552.

Copyright 2019 BMJ Publishing Group. All rights reserved. For permission to reuse any of this content visit

https://www.bmj.com/company/products-services/rights-and-licensing/permissions/

BMJ Case Report Fellows may re-use this article for personal use and teaching without any further permission.

Become a Fellow of BMJ Case Reports today and you can:

- Submit as many cases as you like

- Enjoy fast sympathetic peer review and rapid publication of accepted articles

- Access all the published articles

Re-use any of the published material for personal use and teaching without further permission

Customer Service

If you have any further queries about your subscription, please contact our customer services team on +44 (0) 2071111105 or via email at support@bmj.com.

Visit casereports.bmj.com for more articles like this and to become a Fellow 